\title{
EFEKTIVITAS PEMBELAJARAN FISIKA BERBASIS LESSON STUDY DENGAN MULTIREPRESENTASI UNTUK MELATIH KETERAMPILAN PROSES MAHASISWA PADA MATAKULIAH FISIKA DASAR I
}

\author{
Syahril $^{1)}$, Muhammad Sahal ${ }^{2}$, Fakhruddin $^{3)}$ \\ ${ }^{1,2,3)}$ Program Studi Pendidikan Fisika FKIP, Universitas Riau \\ e-mail: lelsyahril44@yahoo.com
}

\begin{abstract}
Abstrak
Penelitian ini bertujuan untuk mengetahui efektivitas pembelajaran fisika berbasis lesson study dengan multirepresentasi pada matakuliah Fisika Dasar I. Subjek penelitian adalah mahasiswa tingkat pertama sebanyak 42 orang yang dibagi menjadi 2 kelas, yaitu kelas eksperimen dan kontrol. Instrumen pengumpulan data adalah tes keterampilan proses yang terdiri dari 5 item soal essay. Analisis data adalah analisis deskriptif untuk melihat gambaran dari hasil belajar keterampilan proses mahasiswa dengan menggunakan kriteria daya serap, efektivitas pembelajaran, dan ketuntasan belajar siswa pada saat pretest dan postest. Analisis data menunjukkan daya serap rata-rata kelas adalah $9,28 \%$ dengan kategori kurang baik pada kelas eksperimen pretest sedangkan pada postest $17,78 \%$ kurang baik dan 9,30\% dengan kategori kurang baik untuk kelas kontrol pada saat pretest dan $17,18 \%$ dengan kategori kurang baik, sedangkan efektivitas pembelajaran dinyatakan kurang efektif dengan porsentase $0 \%$ pada kelas eksperimen dan $0 \%$ untuk kelas kontrol pada kategori kurang efektif, ketuntasan belajar mahasiswa secara klasikal $0 \%$ dan dinyatakan tidak tuntas pada kelas eksperimen pretest dan $4,76 \%$ dengan kategori tidak tuntas postest, dan $0 \%$ pada saat pretest dengan kategori tidak tuntas, $14,29 \%$ juga tidak tuntas untuk kelas kontrol postest, serta ketuntasan materi pelajaran sebesar $0 \%$ dan dinyatakan tidak tuntas pada kelas eksperimen dan $0 \%$ tidak tuntas pada kelas kontrol baik pretest maupun postest. Dengan demikian, dapat disimpulkan bahwa penerapan pembelajaran fisika berbasis lesson study dengan multirepresentasi efektif digunakan untuk proses pembelajaran mahasiswa pada matakuliah fisika dasar I pada materi tumbukan dan momentum.
\end{abstract}

Kata Kunci: Fisika Dasar I, keterampilan proses, lesson study, multirepresentasi

\begin{abstract}
This study aims to determine the effectiveness of of physics-based learning lesson study with multirepresentasi on Basic Physics course I. The subjects of the study are the first level students as much as 42 people divided into 2 classes, namely experimental and control class. The data completion instrument is a skill test consisting of 5 items about the essay. Data analysis is descriptive analysis to see the picture of result learn student process skill by using absorption criterion, learning efficiency, and mastery learning at presenter and postest. The data analysis showed that the average absorption rate of the class was $9.28 \%$ with the less favorable category in pretest experimental class at posttest $17.78 \%$ less good and 9,30\% with less good category for control class at pretest and 17,18\% With less good category, while the quality of less effective learning with $0 \%$ percentage in the experimental class and $0 \%$ for the control class in the category of less effective, student's $0 \%$ complete student completeness and incomplete start in pretest experimental class and $4.76 \%$ unfinished postest, and $0 \%$ at pretest with unfinished category, $14.29 \%$ also incomplete for postest control class, and $0 \%$ completeness of subject matter and unfinished acceptance in experiment class and $0 \%$ unfinished in control class Pretest and postest Thus, it can be concluded by using the programming language used for learning English on Basic Physics course I on the mater I collision and momentum.
\end{abstract}

Keywords : Basic Physics I, process skills, lesson study, multirepresentation

1) Komunikasi Penulis 


\section{Pendahuluan}

Data Program for International Assessment of Student (PISA) tahun 2009, peringkat Indonesia baru bisa menduduki 10 besar terbawah dari 65 negara. Ada tiga aspek yang diteliti PISA, yakni kemampuan membaca, matematika, dan sains, berikut hasil survey PISA tahun 2009; Reading (57), Matematika (61) dan Sains (60). Dengan predikat ini bisa mencerminkan bagaimana sistem pendidikan Indonesia yang sedang berjalan saat ini. Berdasarkan data PISA tahun 2009 tersebut, anak Indonesia masih rendah dalam kemampuan literasi sains diantaranya mengidentifikasi masalah ilmiah, mengguna kan fakta ilmiah, memahami sistem kehidupan dan memahami penggunaan peralatan sains, selain itu calon mahasiswa yang medaptarkan diri di universitas melalui jalur SNMPTN, SBNPTN dan PBUD yang akan belajar di universitas dengan bekal yang didapatkan sebelumnya.

Sedangkan data Trends in International Mathematics and Science Study (TIMSS) pada tahun 2003 Indonesia berada diurutan 36 dan tahun 2007 diurutan 41. Oleh karena itu, pembaharuan pendidikan di Indonesia memang harus terus dilakukan. Perlu diupayakan penataan pendidikan yang bermutu dan terus menerus. Rendahnya mutu sumber daya manusia Indonesia itu memang tidak terlepas dari hasil yang dicapai oleh pendidikan kita selama ini (BSNP, 2008).

Kenyataan yang sering terjadi di lapangan adalah pendidik lebih mengutamakan nilai akhir dibanding proses pembelajarannya. Pembelajaran fisika yang berfokus terhadap proses dan hasil belajar adalah lebih baik dari pembelajaran fisika yang hanya berfokus pada hasil akhir. Akibatnya, keterampilan proses sains akan menjadi rendah apalagi untuk jenjang pendidikan tinggi. Berdasarkan data tersebut kita dapat menggunakannya sebagai referensi yang baik dalam melakukan penelitian bagi mahasiswa pada matakuliah fisika dasar I, karena mereka merupakan mahasiawa semester awal yang baru saja menginjak bangku pendidikan tinggi yang datang dari berbagai belahan bumi Indonesia. Subjek penelitian ini merupakan sasaran yang tepat yang dapat digunakan untuk melihat apakah efektivitas pembelajaran mahasiswa dengan menggunakan lesson study dapat memberikan gambaran awal dalam mengem bangkan potensi mahasiswa dalam matakuliah lainnya.

Dalam penelitian ini selajutnya peneliti mencoba mengkombinasikan hasil yang diperoleh dari para observer dalam open lesson yang akan dijadikan pedoman dalam melakukan perbaikan pembelajaran bagi mahasiswa pada matakuliah fisika dasar I. Dalam melakukan tes keterampilan proses mahasiswa diharapkan akan menjadi lebih baik dan mampu membuat mahasiswa sadar bahwa dalam proses pembelajaran bukan hanya hasil semata tetapi semua proses pembelajaran yang dapat melibatkan semua aspek yang berkaitan dengan proses pembelajaran dapat berjalan beriringan, seperti halnya melakukan proses terbimbing seperti lesson study dan penerapan strategi pembelajaran multirepresentasi.

Selain itu harapan yang paling tinggi dalam sebuah proses belajar adalah perubahan yang dapat memberikan dampak positif dalam membangun peserta belajar untuk terlibat langsung dalam sebuah proses yang terbimbing yang akan menjadikan mereka lebih memahami apa yang telah mereka pelajari. Adapun teori yang melandasi penelitian ini yaitu teori Lesson Study, pembelajaran multirepresentasi, dan keterampilan proses dalam pembelajaran fisika sebagaimana dijelaskan selanjutnya.

\section{Lesson Study}

Lesson Study merupakan suatu model pembinaan profesi pendidik melalui kegiatan pengkajian pembelajaran yang dilakukan oleh sekelompok pendidik (sipengajar/dosen) secara kolaboratif dan berkelanjutan untuk meningkatkan kualitas pembelajaran. Berdasarkan hasil survei keterlaksanaan dan dampak Lesson Study tahun 2012 dan hasil bimtek tahun 2013 diperoleh simpulan bahwa kegiatan Lesson Study secara umum telah dapat meningatkan kualitas proses perkuliahan dan kompetensi dosen dalam merencanakan dan melaksanakan pem belajaran. Disamping itu Lesson Study telah dirasakan manfaatnya oleh mahasiswa karena banyak dosen telah mengubah kebiasaannya dalam membelajarkan mahasiawa. Perubahan tersebut misalnya lebih tepat waktu, menggunakan media/peralatan pembelajaran yang lebih bervariasi, memberikan perhatian yang lebih banyak pada 
mahasiswa melalui bimbingan belajar dalam kelompok.

Hal-hal positif dari kegiatan Lesson Study belum dialami oleh semua dosen dan selain itu melalui lesson study juga dapat mengukur baik kognitif, keterampilan proses, psikomotor maupun sikap ilmiah mahasiswa maupun mahasiswa. Hal ini sesuai dengan definisi dari lesson study yaitu dalam proses pembelajaran tidak hanya berfokus pada kemampuan sipengajar (pengelolaan kelas dan kompetensi sipengajar) tetapi juga lebih pada kemampuan berfikir peserta didik baik secara kognitif, psikomotorik, proses sains maupun sikap dan sosial.

\section{Pembelajaran Multirepresentasi}

Representasi adalah suatu konfigurasi (bentuk atau susunan) yang dapat menggambarkan, mewakili atau melambang kan suatu cara (Goldin dalam Loviza, 2011). Representasi juga merupakan sesuatu yang menggambarkan, mewakili, atau simbol objek dan atau proses (Rosengrant, Etkina, \& Heuvelen, 2007). Multirepresentasi juga berarti merepresentasi ulang konsep yang sama dengan format yang berbeda, termasuk verbal, gambar, grafik, dan matematik (Prain dan Waldrip, 2007). Menurut M. Yusuf (2009) Ada beberapa alasan pentingnya menggunakan multi representasi :

1. Multikecerdasan (multiple intelligences)

Menurut teori multikecerdasan orang dapat memiliki kecerdasan yang berbedabeda. Oleh karena itu mahasiswa belajar dengan cara yang berbeda-beda sesuai dengan jenis kecerdasannya. Represen tasi yang berbeda-beda memberikan kesempatan belajar yang optimal bagi setiap jenis kecerdasan.

2. Visualisasi bagi otak

Kuantitas dan konsep-konsep yang bersifat fisik seringkali dapat divisualisasi dan dipahami lebih baik dengan menggunakan representasi konkrit.

3. Membantu mengkonstruksi representasi tipe lain

Beberapa representasi konkrit membantu dalam mengkonstruksi representasi yang lebih abstrak.

4. Beberapa representasi bermanfaat bagi penalaran kualitatif. Penalaran kualitatif seringkali terbantu dengan menggunakan representasi konkrit.
5. Representasi matematik yang abstrak digunakan untuk penalaran kuantitatif.

Representasi matematik dapat digunakan untuk mencari jawaban kuantitatif terhadap soal.

Fungsi multirepresentasi dapat dijabar kan sebagai berikut (Ainswort, 1999):

1. Multirepresentasi digunakan untuk mem berikan representasi yang berisi informasi pelengkap.

a) Multirepresentasi melengkapi proses untuk mendapatkan penjelasan mengenai suatu konsep tertentu atau dalam memecahkan soal fisika. Penjelasan secara verbal melalui teks akan menjadi lebih mudah dipahami ketika dilengkapi gambar atau grafik yang relevan dengan informasi yang sedang dibicarakan.

b) Multirepresentasi digunakan untuk melengkapi suatu representasi yang tidak mencukupi untuk menyampai kan informasi atau mungkin terlalu sulit bagi mahasiswa untuk mengartikan representasi tersebut.

2. Multirepresentasi digunakan untuk mem batasi kemungkinan kesalahan menginter pretasi dalam menggunakan representasi lain. Hal ini dapat dicapai melalui dua cara yaitu, memanfaatkan representasi yang bisa dikenal untuk mendukung interpretasi yang kurang bisa dikenal atau lebih abstrak dan menggali sifat-sifat inheren satu representasi untuk membatasi interpretasi representasi kedua.

3. Multirepresentasi dapat digunakan untuk mendorong mahasiswa membangun pema haman yang lebih dalam. Pada fungsi ini, multirepresentasi dapat digunakan untuk meningkatkan abstraksi, membantu generalisasi, dan membangun hubungan antar representasi.

\section{Keterampilan Proses dalam Pembelajaran Fisika}

Richard J. Rezba (dalam Bundu Patta, 2006) memberikan gambaran yang rinci keterkaitan antara keterampilan proses dasar dengan keterampilan proses terintegrasi. Menurut Richard J. Rezba (dalam Susilowati, 2013) ada enam enam keterampilan proses dasar sains yaitu mengamati (observing), mengelompokkan (classifying), mengukur 


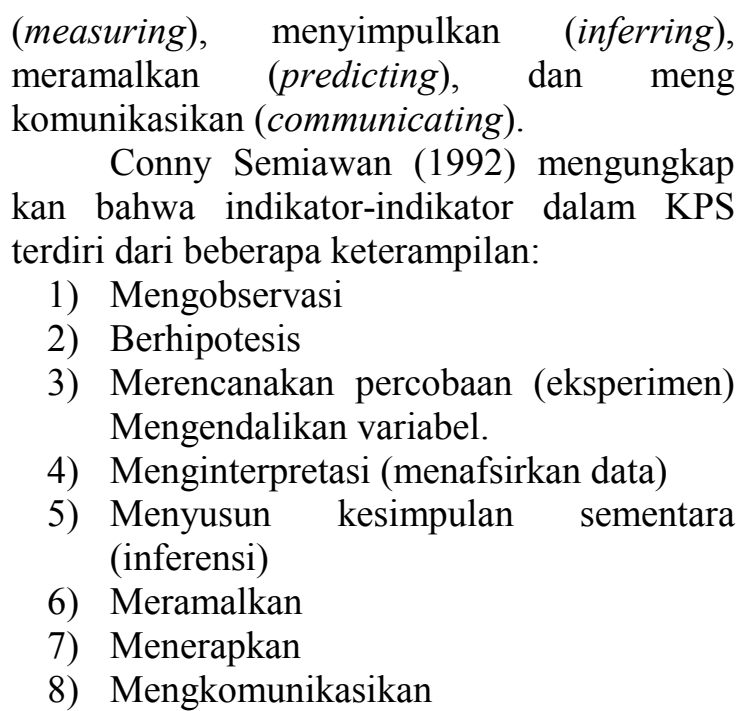

\section{Bahan dan Metode}

Penelitian ini dilakukan di Program Studi Pendidikan Fisika jurusan PMIPA FKIP Universitas Riau, pada bulan Mei sampai Oktober, semester ganjil tahun ajaran 2015/ 2016. Penelitian ini merupakan jenis penelitian quasi eksperimen, dimana variabel penelitian tidak memungkinkan dikontrol secara penuh (Sugiyono, 2011). Tujuan penelitian quasi eksperimen adalah untuk memperoleh informasi yang merupakan perkiraan bagi informasi yang dapat diperoleh dengan eksperimen yang sebenarnya dalam keadaan yang tidak memungkinkan untuk mengontrol semua variable yang relevan (Juliansyah Noor, 2011). Desain yang digunakan adalah Nonequivalent Control Group Design. Disain ini untuk membanding kan kelompok control dan eksperimen tetapi pengambilan kelompok tidak dilakukan secara acak penuh (Nana Syaodih Sukmadinata, 2006). Kedua kelompok diberi pretest sebelum diberi perlakuan. Pada desain ini, kelompok eksperimen diberi suatu perlakuan dan posttest, untuk kelompok control hanya diberi posttest.

Rancangan penelitian menurut Sugiyono (2012) dapat digambarkan pada pola berikut ini:

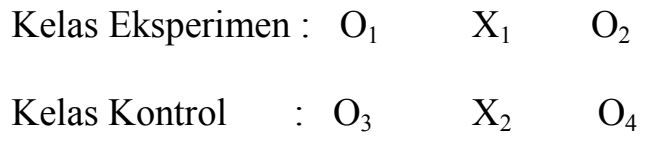

dimana :

$$
\begin{aligned}
\mathrm{O}_{1}, \mathrm{O}_{3}= & \text { Pretst } \\
\mathrm{O}_{2}, \mathrm{O}_{4}= & \text { Postest } \\
\mathrm{X}_{1}= & \text { Perlakuan berbasis lesson study } \\
& \text { dengan strategi pembelajaran } \\
& \text { multirepresentasi } \\
\mathrm{X}_{2}= & \text { Perlakuan dengan strategi } \\
& \text { pembelajaran Multirepresentasi }
\end{aligned}
$$

Subjek penelitian adalah seluruh mahasiawa yang mengambil matakuliah Fisika Dasar I pada semester ganjil tahun ajaran 2015/2016. Teknik pengumpulan data adalah teknik tes berupa pemberian soal keteramilan proses dan menganalisa hasil laporan observer selama open lesson. Pemberian tes dilakukan setelah diberikan pembelajaran berbasis lesson study dengan pembelajaran multirepresentasi. Teknik analisis yang digunakan adalah analisis deskriptif. Analisis deskriptif digunakan untuk melihat gambaran hasil belajar keterampilan proses sains fisika mahasiswa dengan menggunakan kriteria daya serap dan efektivitas pembelajaran.

Daya serap dan efektivitas pembelajaran ditentukan berdasarkan Tabel 1.

Tabel 1. Kategori daya serap dan efektivitas pembelajaran

\begin{tabular}{cll}
\hline $\begin{array}{c}\text { Interval } \\
(\%)\end{array}$ & $\begin{array}{c}\text { Kategori Daya } \\
\text { Serap }\end{array}$ & $\begin{array}{c}\text { Kategori } \\
\text { Efektivitas }\end{array}$ \\
\hline $85-100$ & Amat Baik & Sangat efektif \\
$70-84$ & Baik & Efektif \\
$50-69$ & Cukup Baik & Cukup Efektif \\
$0-49$ & Kurang Baik & Kurang Efektif
\end{tabular}

Sumber: (Depdiknas, 2007)

Ketuntasan keterampilan proses sains fisika terdiri dari ketuntasan individual, ketuntasan belajar klasikal, ketuntasan tujuan pembelajaran dan ketuntasan materi pembelajaran. Ketuntasan individual mahasiswa dikatakan tuntas apabila mencapai skor $\geq 75 \%$, ketuntasan belajar klasikal tuntas apabila suatu kelas telah mencapai $\geq 85 \%$ maka kelas itu dikatakan tuntas, ketuntasan tujuan pembelajaran dikatakan tuntas apabila $\geq 75 \%$ dari jumlah mahasiswa menjawab benar tujuan pembelajaran tersebut, dan ketuntasan materi pembelajaran dinyatakan tuntas apabila $\geq 85 \%$ dari seluruh tujuan pembelajaran tuntas. Adapun kriteria 
penarikan kesimpulan yaitu jika daya serap rata-rata kelas dalam kategori amat baik atau baik, maka penerapan pembelajaran berbasis multirepresentasi dan multirepresentasi berbasis lesson study efektif diterapkan pada materi momentum dan tumbukan serta dapat melatih keterampilan proses sains mahasiswa.

\section{Hasil dan Pembahasan}

Analisa data dalam penelitian ini merupakan analisa data keterampilan proses fisika dalam matakuliah Fisika Dasar I pada materi tumbukan dan momentum untuk kelas eksperimen dan kontrol, yang terdiri dari data pretest dan postest. Adapun analisa secara keseluruhan dapat dilihat pada Tabel 2.

Tabel 2 menunjukkan bahwa daya serap mahasiswa adalah 9,28 \% dengan kategori Kurang Baik (KB), ketuntasan belajar klasikal tidak tuntas (TT) $0 \%$ dan ketuntasan materi pelajaran juga tidak tuntas (TT) $0 \%$ pada saat pretest, hal ini dikarenakan mahasiswa hanya menggunakan kemampuan mereka sewaktu belajar di SLTA tentang materi tumbukan dan momentum dimana tes yang diberikan sangat bergantung pada pemahaman mereka disaat itu. Sedangkan pada saat postes daya serapnya menngalami peningkatan yaitu 17,78 \% dengan kategori juga kurang baik (KB), efektivitas pembelajaran tidak efektif (TE) $0 \%$, ketuntasan belajar klasikal tidak tuntas (TT) $4,76 \%$ dan ketuntasan materi pelajaran tidak tuntas (TT) $0 \%$, hal ini dikarenakan mahasiswa telah mulai memahami materi yang diajarkan yang diiringi dengan proses belajar multirepresentasi berbasis lesson study, dimana selama proses pembelajaran berlangsung dosen semaksimal mungkin membimbing mahasiswa dalam kerja kelompok.

Oleh karena dalam penelitian ini telah menerapkan pendekatan multirepresentasi berbasis lesson study, maka suasana belajar yang terjadi adalah sangat menarik dan dapat meningkatkan minat serta mendorong mahasiswa dalam mengerjakan soal-soal dan diskusi yang sangat memungkinkan mahasiswa terpacu untuk saling memberikan kontribusi yang terbaik dalam kerja kelompok maupun individu. Pernyataan ini diperoleh dari para ovserver yang ada pada saat berlangsungnya proses belajar mengajar pada pertemuan pertama dan kedua yang terdiri dari 3 orang. Namun pada pertemuan pertama ada hal-hal yang terabaikan terutama pada saat mahasiswa melakukan peragaan sesuai LKM-4 yang ada terutama pada indikator ketiga yaitu mengklasifikasikan benda lenting sempurna, lenting sebagian dan tidak lenting sama sekali. Hal ini sudah dapat diatasi pada pertemuan kedua.

a. Lesson Study dan Multirepresentasi (Kelas Eksperimen)

Selama proses pembelajaran baik pertemuan pertama maupun kedua,

Tabel 2. Deskripsi hasil belajar keterampilan proses Fisika Dasar I kelas eksperimen

\begin{tabular}{clcccc}
\hline \multirow{2}{*}{ No } & \multicolumn{1}{c}{$\begin{array}{c}\text { Aspek Analisis } \\
\text { Deskriptif }\end{array}$} & \multicolumn{2}{c}{ Pretest } & \multicolumn{2}{c}{ Postest } \\
\hline & \multicolumn{1}{c}{ Porsentase } & Kategori & Persentase & Kategori \\
\hline 1 & $\begin{array}{l}\text { Daya Serap Rata-rata } \\
\text { Mahasiswa }\end{array}$ & 9,28 & KB & 17,78 & KB \\
2 & $\begin{array}{l}\text { Efektivitas } \\
\text { Pembelajaran }\end{array}$ & $\mathbf{0}$ & KE & 0 & KE \\
3 & $\begin{array}{l}\text { Ketuntasan Belajar } \\
\text { Klasikal }\end{array}$ & 0 & TT & 4,76 & TT \\
Ketuntasan Materi & 0 & TT & 0 & TT \\
\hline Pelajaran
\end{tabular}

Ket : KB= Kurang Baik; KE= Kurang Efektif; TT = Tidak Tuntas 
mahasiswa sangat besemangat dalam mengerjakan semua yang ditugaskan. Hal ini terlihat dari hasil pemantauan para ovserver untuk setiap kelompok namun ada beberapa mahasiswa yang sedikit pakum selama proses pembelajaran terutama pada pertemuan pertama. Hal ini sudah dapat diatasi pada pertemuan kedua, dan terlihat hampir semua peserta memberikan kontribusi untuk kelompok mereka. Padahal pada pertemuan pertama mereka lebih banyak menonjolkan kepentingan individu, namun pada pertemuan kedua dosen lebih bisa mengarahkan mereka untuk saling memberikan kontribusi yang dapat membangun kepentingan kelompok dalam belajar, Apalagi dalam pembelajaran ini mutirepresentasi yang diterapkan berjalan sebagaimana mestinya dan banyak asumsi-asumsi yang mereka buat sesuai dengan apa yang pernah mereka dapatkan tentang tumbukan dan momentum. Ditambah lagi dengan bimbingan selama pembelajaran sehingga mereka mulai mengerti dengan apa yang telah disampaikan.

b. Multirepresntasi (Kelas Kontrol)
Dalam penerapan multirepresntasi untuk kelas kontrol, dimana mahasiswa memberikan kontribusi yang cukup besar selain kontribusi dosen tentang materi yang disajikan, artinya dosen lebih menekankan pada pembelajaran berpusat pada dosen (teacher center learning) dan lebih menekankan pada model kurikulum subjek akademik serta model pedidikan klasik. Ternya hal ini sangat berpengaruh pada hasil yang diperoleh mahasiswa sbagaimana tergambar pada Tabel 3, dimana untuk skor daya serap memiliki porsentase yang sama yaitu $17,78 \%$ pada saat postest, namun untuk skor ketuntasan kelas kontrol lebih baik yaitu $14,29 \%$ sementara untuk kelas eksperimen hanya $4,76 \%$.

Tabel 3 menunjukkan bahwa daya serap mahasiswa adalah 9,30\% dengan kategori kurang baik (KB), ketuntasan belajar klasikal tidak tuntas (TT) $0 \%$ dan ketuntasan materi pelajaran juga tidak tuntas (TT) $0 \%$ pada saat pretest, hal ini dikarenakan mahasiswa hanya menggunakan kemampuan mereka sewaktu mereka belajar di SLTA tentang materi tumbukan dan momentum dimana tes yang diberikan sangat bergantung pada pemahaman mereka disaat itu.

Tabel 3. Deskripsi hasil belajar keterampilan proses Fisika Dasar I kelas kontrol

\begin{tabular}{clcccc}
\hline No & \multicolumn{1}{c}{$\begin{array}{c}\text { Aspek Analisis } \\
\text { Deskriptif }\end{array}$} & \multicolumn{2}{c}{ Pretest } & \multicolumn{2}{c}{ Postest } \\
\hline & \multicolumn{1}{c}{ Porsentase } & Kategori & Porsentase & Kategori \\
\hline 1 & $\begin{array}{l}\text { Daya Serap Rata- } \\
\text { rata Mahasiswa }\end{array}$ & 9,30 & KB & 17,18 & KB \\
2 & $\begin{array}{l}\text { Efektivitas } \\
\text { Pembelajaran }\end{array}$ & $\mathbf{0}$ & $\boldsymbol{K E}$ & 0 & KE \\
3 & $\begin{array}{l}\text { Ketuntasan Belajar } \\
\text { Klasikal }\end{array}$ & 4,76 & TT & 14,29 & TT \\
4 & $\begin{array}{l}\text { Ketuntasan Materi } \\
\text { Pelajaran }\end{array}$ & 0 & TT & 0 & TT \\
\hline
\end{tabular}

Ket : KB= Kurang Baik; KE= Kurang Efektif; $\mathrm{TT}=$ Tidak Tuntas 
Sedangkan pada saat postes daya serapnya menngalami peningkatan yaitu $17,78 \%$ dengan kategori Kurang Baik (KB), efektivitas pembelajaran tidak efektif (TE) $0 \%$, ketuntasan belajar klasikal tidak tuntas (TT) $14,29 \%$ dan ketuntasan materi pelajaran tidak tuntas (TT) $0 \%$, dibandingkan pada kelas eksperimen porsentase ketuntasan balajar kelasikal sedikit mengalami peningkatan yaitu $4,76 \%$ pada saat postest dan 14,29 pretest, hal ini dikarenakan mahasiswa lebih bannyak berfokus pada apa yang telah disajikan dosen pada saat belajar mengajar yang mana pada kelas kontrol dosen lebih menekankan pembelajaran yang berpusat pada dosen atau pengajar yang beorientasi pada model pendidikan klasik dengan model kurikulum subjek akademik baik pada pertemuan pertama maupun kedua.

Pada Tabel 4 untuk kelas eksperimen daya serap untuk setiap indikator dengan kategori kurang baik (KB) dan secara keseluruhan juga kurang baik (KB) yaitu $9,28 \%$ pada pretest. Sedangkan untuk postest $17,78 \%$ dengan kategori kurang baik (KB).

Namun indikator yang paling mengalami peningkatan adalah indikator ke empat "Merencanakan Percobaan" yaitu dari $1,10 \%$ menjadi $7,43 \%$. Hal ini dikarenakan pada indikator ini lebih menarik dan lebih nyata dalam kehidupan sehari-hari terutama dalam penerapan kemiliteran sehingga mahasiswa baru menyadari bahwa cara yang paling mudah untuk menentukan kecepatan peluru (balestik) adalah dengan menggunakan bandul balestik dan ini adalah indikator yang paling banyak mendapat pertanyaan dan diskusi.

Pada Tabel 5 untuk kelas kontrol daya serap untuk setiap indikator dengan kategori kurang baik (KB) dan secara keseluruhan juga kurang baik $(\mathrm{KB})$ yaitu $9,30 \%$ pada pretest. Sedangkan untuk postest $17,78 \%$ dengan kategori kurang baik (KB). Namun indikator yang paling mengalami peningkatan adalah indikator ke dua "Mengidentifikasi Grafik" yaitu dari 3,67\% menjadi $11,19 \%$.

Hal ini dikarenakan pada indikator ini lebih menekankan pada arti fisis yang ada dibalik garfik yaitu keterkaitan antara gaya dan waktu yang berimbas pada efek yang ditimbulkan pada suatu benda, misalnya ketika dua benda yang sama dijatuhkan pada ketinggian yang sama maka rusak atau tidak rusaknya suatu benda tidak bergantung pada energi potensial dengan ketinggian tetentu namun bengantung pada waktu sentuh benda sampai berhenti.

Tabel 4. Daya serap keterampilan proses mahasiswa kelas eksperimen

\begin{tabular}{|c|c|c|c|c|c|}
\hline \multirow[b]{2}{*}{ No } & \multirow[b]{2}{*}{ Indikator / TP } & \multicolumn{2}{|c|}{ Pretest } & \multicolumn{2}{|c|}{ Postest } \\
\hline & & $\begin{array}{l}\text { Rata-rata Daya } \\
\text { Serap } \\
\text { Mahasiswa (\%) }\end{array}$ & Kategori & $\begin{array}{l}\text { Rata-rata Daya } \\
\text { Serap } \\
\text { Mahasiswa (\%) }\end{array}$ & Kategori \\
\hline 1 & Memprediksi & 35,24 & KB & 58,33 & $\mathrm{CB}$ \\
\hline 2 & $\begin{array}{l}\text { Mengidentifikasi } \\
\text { Grafik }\end{array}$ & 3,62 & KB & 9,86 & KB \\
\hline 3 & Mengklasifikasi & 4,86 & $\mathrm{~KB}$ & 8,95 & KB \\
\hline 4 & $\begin{array}{l}\text { Merencanakan } \\
\text { Percobaan }\end{array}$ & 1,10 & $\mathrm{~KB}$ & 7,43 & KB \\
\hline 5 & $\begin{array}{l}\text { Mengidentifikasi } \\
\text { Variabel }\end{array}$ & 1,57 & KB & 4,33 & KB \\
\hline $\begin{array}{l}\text { Daya } \\
\text { untu }\end{array}$ & $\begin{array}{l}\text { erap Rata-rata Kelas } \\
\text { Seluruh TP }\end{array}$ & 9,28 & & 17,78 & \\
\hline & Kategori & & KB & & KB \\
\hline
\end{tabular}

Ket : $\mathrm{KB}=$ Kurang Baik; $\mathrm{CB}=$ Cukup Baik 
Tabel 5. Daya serap keterampilan proses mahasiswa kelas kontrol

\begin{tabular}{|c|c|c|c|c|c|}
\hline \multirow[b]{2}{*}{ No } & \multirow[b]{2}{*}{ Indikator / TP } & \multicolumn{2}{|c|}{ Pretest } & \multicolumn{2}{|c|}{ Postest } \\
\hline & & $\begin{array}{c}\text { Rata-rata } \\
\text { Daya Serap } \\
\text { Mahasiswa (\%) }\end{array}$ & Kategori & $\begin{array}{c}\text { Rata-rata } \\
\text { Daya Serap } \\
\text { Mahasiswa (\%) }\end{array}$ & Kategori \\
\hline 1 & Memprediksi & 38,81 & KB & 54,29 & CB \\
\hline 2 & $\begin{array}{l}\text { Mengidentifikasi } \\
\text { Grafik }\end{array}$ & 3,67 & $\mathrm{~KB}$ & 11,19 & $\mathrm{~KB}$ \\
\hline 3 & Mengklasifikasi & 4,19 & $\mathrm{~KB}$ & 8,14 & KB \\
\hline 4 & $\begin{array}{l}\text { Merencanakan } \\
\text { Percobaan }\end{array}$ & 1,95 & KB & 7,62 & KB \\
\hline 5 & $\begin{array}{l}\text { Mengidentifikasi } \\
\text { Variabel }\end{array}$ & 2,90 & $\mathrm{~KB}$ & 4,67 & $\mathrm{~KB}$ \\
\hline $\begin{array}{l}\text { Daya } \\
\text { untuk }\end{array}$ & $\begin{array}{l}\text { Serap Rata-rata Kelas } \\
\text { Seluruh TP } \\
\text { Kategori }\end{array}$ & 9,30 & $\mathrm{~KB}$ & 17,18 & $\mathrm{~KB}$ \\
\hline
\end{tabular}

Ket : $\mathrm{KB}=$ Kurang Baik; $\mathrm{CB}=$ Cukup Baik; $\mathrm{KE}=$ Kurang Efektif; $\mathrm{TT}=$ Tidak Tuntas

Tabel 6. Efektivitas pembelajaran keterampilan proses mahasiswa kelas eksperimen

\begin{tabular}{|c|c|c|c|c|}
\hline \multirow[b]{2}{*}{ Tujuan Pembelajaran } & \multicolumn{2}{|c|}{ Pretest } & \multicolumn{2}{|c|}{ Postest } \\
\hline & $\begin{array}{c}\text { Rata-rata } \\
\text { Efektivitas } \\
(\%)\end{array}$ & $\begin{array}{l}\text { Kategori } \\
\text { Efektivitas }\end{array}$ & $\begin{array}{c}\text { Rata-rata } \\
\text { Efektivitas } \\
(\%)\end{array}$ & $\begin{array}{l}\text { Kategori } \\
\text { Efektivitas }\end{array}$ \\
\hline TP I & 35,24 & $K E$ & 58,33 & CE \\
\hline TP II & 3,62 & $K E$ & 9,86 & KE \\
\hline TP III & 4,86 & $K E$ & 8,95 & $\mathrm{KE}$ \\
\hline TP IV & 1,10 & $K E$ & 7,43 & $\mathrm{KE}$ \\
\hline TP V & 1,57 & $K E$ & 4,33 & $\mathrm{KE}$ \\
\hline $\begin{array}{l}\text { Efektivitas Pembelajaran } \\
\text { Keseluruhan TP }\end{array}$ & 0 & $\mathrm{KE}$ & 0 & KE \\
\hline
\end{tabular}

Ket : KE= Kurang Efektif; $\mathrm{CE}=$ Cukup Efektif

Berdasarkan Tabel 6 efektivitas pembelajaran untuk setiap indikator rata-rata adalah kurang efektif (KE) untuk kelas eksperimen tetapi ada satu indikator yang berada pada kategori cukup efektif (CE) yaitu $58,33 \%$ pada saat postest.

Hal ini dikarenakan pada indikator pertama "Memprediksi" arah gerak benda setelah tumbukan sehingga hampir sebagian besar mahasiswa menjawab dengan asumsiasumsi yang mendekati kebenaran dan ini sesuai dengan pembelajaran multirepresntasi yang memungkinkan mahasiswa dengan pengalamannya yang pernah mempelajari ini menjadi modal awal buat mereka untuk menjawab soal tersebut. Khusus untuk indikator ini kelas eksperimen sedikit lebih baik dibandingkan kelas kontrol yaitu 54,29 \% cukup efektif (CE), hal ini menunjukkan bahwa pada indikator ini jumlah mahasiswa yang tuntas lebih banyak dibandingkan pada indikator yang lain.

Berdasarkan Tabel 7 efektivitas pembelajaran untuk setiap indikator rata-rata adalah kurang efektif (KE) untuk kelas kontrol tetapi ada satu indikator yang berada pada kategori cukup efektif (CE) yaitu $54,29 \%$ pada saat postest. Hal ini dikarenakan pada indikator pertama "memprediksi" arah gerak benda setelah tumbukan sehingga 
hampir sebagian besar mahasiswa menjawab dengan asumsi-asumsi yang mendekati kebenaran dan ini sesuai dengan pembelajaran multirepresntasi yang memungkinkan mahasiswa dengan pengalamannya yang pernah mempelajari ini menjadi modal awal buat mereka untuk menjawab soal tersebut.

Tabel 7. Efektivitas pembelajaran keterampilan proses mahasiswa kelas kontrol

\begin{tabular}{|c|c|c|c|c|}
\hline \multirow[b]{2}{*}{ Tujuan Pembelajaran } & \multicolumn{2}{|c|}{ Pretest } & \multicolumn{2}{|c|}{ Postest } \\
\hline & $\begin{array}{c}\text { Rata-rata } \\
\text { Efektivitas } \\
(\%)\end{array}$ & $\begin{array}{l}\text { Kategori } \\
\text { Efektivitas }\end{array}$ & $\begin{array}{c}\text { Rata-rata } \\
\text { Efektivitas (\%) }\end{array}$ & $\begin{array}{c}\text { Kategori } \\
\text { Efektivitas }\end{array}$ \\
\hline TP I & 33,81 & $K E$ & 54,29 & $\mathrm{CE}$ \\
\hline TP II & 3,67 & $K E$ & 11,19 & $\mathrm{KE}$ \\
\hline TP III & 4,19 & $K E$ & 8,14 & $\mathrm{KE}$ \\
\hline TP IV & 1,95 & $K E$ & 7,62 & $\mathrm{KE}$ \\
\hline TP V & 2,90 & $K E$ & 4,67 & $\mathrm{KE}$ \\
\hline $\begin{array}{c}\text { Efektivitas } \\
\text { Pembelajaran } \\
\text { Keseluruhan TP }\end{array}$ & 0 & $\mathrm{KE}$ & 0 & $\mathrm{KE}$ \\
\hline
\end{tabular}

Ket : KE $=$ Kurang Efektif; $\mathrm{CE}=$ Cukup Efektif

Tabel 8. Ketuntasan butir tujuan pembelajaran keterampilan proses kelas eksperimen

\begin{tabular}{ccccccc}
\hline & \multicolumn{3}{c}{ Pretest } & & Postest \\
\cline { 2 - 7 } TP & $\begin{array}{c}\text { Jlh Mhs } \\
\text { yang Tuntas }\end{array}$ & $\begin{array}{c}\text { Porsentase } \\
(\%)\end{array}$ & $\begin{array}{c}\text { Kategori } \\
\text { Ketuntasan }\end{array}$ & $\begin{array}{c}\text { Jlh Mhs yang } \\
\text { Tuntas }\end{array}$ & $\begin{array}{c}\text { Porsentase } \\
(\%)\end{array}$ & $\begin{array}{c}\text { Kategori } \\
\text { Ketuntasan }\end{array}$ \\
\hline 1 & 4 & 19,05 & TT & 10 & 47,62 & TT \\
2 & 2 & 9,52 & TT & 8 & 38,10 & TT \\
3 & 2 & 9,52 & TT & 4 & 19,05 & TT \\
4 & 0 & 0 & TT & 3 & 14,29 & TT \\
4 & 1 & 4,76 & TT & 1 & 4,76 & TT \\
\hline
\end{tabular}

Ket: TT= Tidak Tuntas

Tabel 9. Ketuntasan butir tujuan pembelajaran keterampilan proses kelas kontrol

\begin{tabular}{|c|c|c|c|c|c|c|}
\hline \multirow[b]{2}{*}{ TP } & \multicolumn{3}{|c|}{ Pretest } & \multicolumn{3}{|c|}{ Postest } \\
\hline & $\begin{array}{c}\text { Jlh Mhs } \\
\text { yang Tuntas }\end{array}$ & $\begin{array}{c}\text { Porsentase } \\
(\%)\end{array}$ & $\begin{array}{l}\text { Kategori } \\
\text { Ketuntasan }\end{array}$ & $\begin{array}{c}\text { Jlh Mhs yang } \\
\text { Tuntas }\end{array}$ & $\begin{array}{c}\text { Porsentase } \\
(\%)\end{array}$ & $\begin{array}{l}\text { Kategori } \\
\text { Ketuntasan }\end{array}$ \\
\hline 1 & 8 & 38,10 & TT & 9 & 42,86 & TT \\
\hline 2 & 2 & 9,52 & TT & 12 & 57,14 & TT \\
\hline 3 & 5 & 23,81 & TT & 7 & 33,33 & TT \\
\hline 4 & 2 & 9,52 & TT & 5 & 23,81 & TT \\
\hline 4 & 3 & 14,29 & TT & 3 & 14,29 & TT \\
\hline
\end{tabular}

Ket: TT $=$ Tidak Tuntas 
Tabel 8 menunjukkan ketuntasan butir tujuan pembelajaran pada kelas eksperimen, dari semua tujuan pembelajaran rata-rata mengalami peningkatan namun tidak tuntas (TT). Sedangkan peningkatan yang paling besar adalah pada indikator pertama "memprediksi" dan kedua "mengidentifikasi grafik".

Pada saat pretest jumlah mahasiswa yang tuntas adalah 4 orang sedangkan pada postest adalah 10 orang, sedangkan untuk indikator kedua pada saat pretest 2 orang dan postest 8 orang. Hal ini dikarenakan kedua tujuan pembelajaran ini merupakan tujuan pembelajaran dengan tingkat keterampilan proses yang paling rendah.

Tabel 9 menunjukkan ketuntasan butir tujuan pembelajaran pada kelas kontrol, dari semua tujuan pembelajaran rata-rata mengalami peningkatan namun tidak tuntas (TT). Sedangkan peningkatan yang paling besar adalah pada indikator kedua "mengidentifikasi grafik". Pada saat pretest jumlah mahasiswa yang tuntas adalah 2 orang sedangkan pada postest adalah 12 orang, sedangkan untuk indikator pertama pada saat pretest 8 orang dan postest 9 orang.

Hal ini dikarenakan kedua tujuan pembelajaran ini merupakan tujuan pem belajaran dengan tingkat keterampilan proses yang paling rendah. Khusus untuk indikator pertama kelas kontrol lebih stabil dan meningkat, hal ini dikarenakan pada indikator ini jawaban yang mungkin sudah tergambar dari konstruksi soal dan ditambah dengan proses pembelajaran yang befokus pada dosen yang lebih banyak menjelaskan tetang konsep pada indikator ini, sehingga mahasiswa paham dengan yang telah dijelaskan. Sementara untuk tujuan pembelajaran kedua "mengidentifikasi grafik", konsep yang diberikan pada saat belajar mengajar menjadi pusat perhatian mahasiswa yang memunculkan argumen mahasiswa yang lebih baik sehingga berimbas pada kemampuan menjawab soal pada tujuan pembelajaran ini.

\section{Kesimpulan dan Saran}

Adapun kesimpulan yang diperoleh dalam penelitian ini adalah: 1) Daya serap rata-rata mahasiswa $9,28 \%$ pada kategori kurang baik (KB) untuk kelas eksperimen pada saat pretest, dan kategori kurang baik (KB) pada saat postest yaitu $17,78 \%$. 2) Daya serap rata-rata mahasiswa 9,30\% pada kategori kurang baik (KB) untuk kelas kontrol pada saat pretest, dan kategori kurang baik (KB) pada saat postest yaitu $17,78 \%$. 3) Efetivitas pembelajaran kurang efektif (KE) pada kelas eksperimen maupun kelas control pada saat postest. 4) Ketuntasan belajar kelasikal tidak tuntas (TT) pada kelas eksperimen pada saat pretes yaitu $0 \%$ dan postest $\quad 4,76 \%$ tidak tuntas (TT). 5) Ketuntasan belajar kelasikal tidak tuntas (TT) pada kelas kontrol pada saat pretes yaitu $4,76 \%$ dan postest $14,29 \%$ tidak tuntas (TT). 6) Ketuntasan materi pelajaran untuk kelas eksperimen pada saat pretest $0 \%$ tidak tuntas (TT) dan posttest $0 \%$ tidak tuntas (TT). 7) Ketuntasan materi pelajaran untuk kelas kontrol pada saat pretest $0 \%$ tidak tuntas (TT) dan posttest $0 \%$ tidak tuntas (TT). 8) Secara keseluruhan dapat disimpulkan pembelajaran multirepresntsi berbasis lesson study tidak efektif untuk materi tumbukan dan momentum.

Dengan demikian, penerapan Pem belajaran fisika berbasis Lesson Study dengan multirepresentasi tidak efektif untuk melatih keterampilan proses mahasiswa pada matakuliah Fisika Dasar I pada materi tumbukan dan momentum tahuan akademik 2015/2016.

\section{Daftar Pustaka}

Ainsworth, S., 1999. The Functions of Multiple Representations. Computers and Educa tion, 33, 131-152. (diakses tanggal 10 Agustus 2015).

Angell, C, O. Guttersrud, dan E. K. Henriksen, 2007. Multiple Representation As A Framework For A Modelling Approach to Physics Education. (diakses tanggal 20 September 2015).

Bambang Hudiono, 2010. Peran Pembelajaran Diskursus Multi Representasi terhadap Pengembangan Kemampuan Mate matika dan Daya Representasi pada Siswa SLTP. Jurnal Cakrawala Kependidikan Vol. 8, No.1. Pendidikan Matematika FKIP Universitas Tanjung 
pura. Pontianak. (diakses 04 Januari 2015).

Bundu, Patta, 2006. Penilaian Keterampilan Proses dan Sikap Ilmiah dalam Pembelajaran Sains. Depdiknas, Jakarta.

Conny Semiawan, 1992. Pendekatan Keterampilan Proses. Gramedia Widisarana Indonesia, Jakarta.

Dimyati, dan Mudjiono, 2006. Belajar dan Pembelajaran. Rieneka Cipta, Jakarta.

Dufresne, R, Gerace, W, Leonard, W. 2004. Solving Physics Problems with Multiple Representation. (Online). http://srri. umass.edu/files/dufresne- 1997spp.pdf. (diakses tanggal 18 September 2015).

Haratua, Fitria, Tomo, R., 2013. Penggunaan Model Problem Based Learning dengan Multipresentasi pada Usaha dan Energi di SMA. Jurnal FMIPA ITB. Vol.4, No.3. Program Studi Pendidikan Fisika FKIP Universitas Tanjungpura. Pontianak. (diakses 04 Januari 2015).

Loviza, U., 2011. Penggunaan Pendekatan Multi Representasi Pada Pembelajaran konsep Gerak Untuk Meningkatkan Pemahaman Konsep Dan Memperkecil Kuantitas Miskonsepsi Siswa SMP. Program Pascasarjana Universitas Pendidikan Indonesia. Bandung.

Prain, V., and Waldrip, B.G., 2007. An Exploratory Study Of Teachers' Perspectives About Using Multi-Modal
Representations Of Concepts To Enhance Science Learning. Canadian Journal of Science, Mathematics and Technology Education. (diakses tanggal 10 Agustus 2015).

Rizky,G., 2014. Kemampuan Multirepresen tasi Siswa SMA dalam Menyelesa kan Soal-soal Hukum Newton. Jurnal Pendidikan dan Pembelajaran Vol. 3 No. 8. Program Studi Pendidikan Fisika. Universitas Tanjungpura.

Rosengrant, D., Etkina, E., \& Heuvelen, A.V., 2007. An Overview of Recent Research on Multiple Representations. Rutgers, The State University of New Jersey GSE, 10 Seminary Place, New Brunswick NJ, 08904. (diakses tanggal 12 September 2015).

Rustaman, Nuryani, 2007. Keterampilan Proses Sains. SPS UPI, Bandung.

Sugiyono, 2012. Metode Penelitian Pendidi kan Pendekatan Kuantitatif, Kualitatif, dan $R \& D$. Alfabeta, Bandung.

Suhandi \& Wibowo F.C., 2012. Pendekatan Multirepresentasi dalam Pembelajaran Usaha Energi dan Dampak terhadap Pemahaman Konsep Mahasiawa. Jurnal Pendidikan Fisika Indonesia 8 (2012) 1-7. FKIP Univesitas Pendidikan Indonesia, Bandung.

Trianto, 2007. Model-model Pembelajaran Inovatif Berorientasi Kontrutivistik. Prestasi Pustaka, Jakarta. 